\title{
Making Scotch Respectable: Buchanan and Walker
}

Many were aware of whisky's shortcomings and idiosyncrasies. Grain whiskies were smooth but dull. Malts had flavour and charisma, but varied from batch to batch. The solution was blended whisky which combined grain and malt and ironed out their inconsistencies to give a consistently good drink. ${ }^{1}$

The trade in blended whisky expanded in the second half of the nineteenth century. This was the period of the so-called 'whisky tide' when Scotch whisky became a popular drink south of the border. Spiller believes that the popularity of Scotch whisky is linked to Walter Scott romanticism, the growth in Highland tourism and the grouse season attracting high society. ${ }^{2}$ The idea of a good Scotch was appealing but as the quote above suggests, the quality and taste of single malt or grain whiskies varied. Several key events led to the growth and development of the trade in blended whisky in the second half of the nineteenth century. The spread of the railway system in the 1850s had opened up the English market to Scottish products more generally. ${ }^{3}$ The trade in whisky expanded after the passing of The 1860 Spirits Act which allowed the blending of spirits in bonded warehouses without the payment of duty. The initial purpose of whisky blending was to reduce the cost of pure malt by mixing it with cheaper grain spirit made using the patent still method. In 1865, The Scotch Distillers Association was formed through an amalgamation of six major distillers looking to secure the future of their businesses by regulating the price and output of grain whisky. ${ }^{4}$ https://doi.org/10.1007/978-3-319-92964-4_7 
As Ronald Weir notes, between 1870 and 1914, distillers operated in a highly competitive free trade environment. ${ }^{5}$ In 1870 , the total output of home-produced spirits was 24.4 million proof gallons ( $\mathrm{mpg}$ ) and this rose in 1900 to a total output of $42.8 \mathrm{mpg}^{6}{ }^{6}$

These events occurred around the same time as the Phylloxera plant disease wiped out an estimated one-third to a half of French vineyards. This impacted upon the availability of brandy in England and thus created a niche in the market for the sale of whisky. Brandy was the preferred drink of the middle-and upper-classes and therefore in order to fill the gap in the brandy market, whisky had to be marketed as a suitable replacement and had to appeal to the tastes of English consumers. Spanish sherry was another popular drink in the nineteenth century and it was common for empty sherry barrels to be used by distillers to mature whisky. Consequently, the whisky matured in sherry barrels tasted like brandy. ${ }^{7}$ By the 1890s, there was large-scale production of blended whiskies in Scotland which led to increased competition in both the domestic and foreign markets for whisky. Successful companies like Buchanan, Dewar and Walker (known as 'the big three') made their fortunes from the production and sale of blended whiskies that were developed primarily for the English market. The success of these products rested in part on the skill of blenders to create Scotch that suited the English palate and also on the ability of companies to market scotch as a viable alternative to brandy that would appeal to the middle-and upper-classes.

The transformation of an ordinary commodity like blended whisky into Scotch, which became a status drink among the social elites, involved targeting specific groups of consumers and selling them particular ideas about the substance and James Buchanan did this very successfully. When Buchanan (who became Lord Woolavington) died in 1935, the Daily Express ran his obituary with the headline: 'The secret that made Lord Woolavington: He found the formula for making England like Scotch Whisky.' The article went on to report that Lord Woolavington had the reputation of being the wealthiest of the great whisky distillers of modern times. He started work as a clerk and the secret of his success was he found a formula for making Scotch whisky that was palatable to Englishmen. ${ }^{8}$ James Buchanan (1849-1935) began life as the son of a Scottish farmer and ended it as Baron Woolavington-businessman, entrepreneur, philanthropist and multimillionaire. Buchanan was an astute businessman, an opportunist and a risk taker-some of the key characteristics that defined the ideals of British imperial masculinity. 
In 1879, Buchanan left his employment in the grain trade in Glasgow and moved to London to work for a whisky firm. By 1884, he had accumulated enough knowledge and contacts in the whisky trade to start his own business. ${ }^{9}$ As the retail side of the business grew, Buchanan began a process of backward integration to control the entire whisky manufacturing process through the purchase and control of distillers and bottling plants and in 1903 the company was registered as a limited company. ${ }^{10}$ Ronald Weir believes that the success of Buchanan's early business strategy was down to his determination to climb the social ladder and seek prestigious clients and outlets for his products. ${ }^{11}$ Buchanan was adept at selling his whisky in desirable places and to influential people. He doggedly pursued contracts and quickly managed to get his blend of whisky sold in London hotels, theatres and other prominent drinking venues. As Spiller notes, the House of Commons contract in 1885 was a significant coup that highlights two key features of Buchanan's sales strategy: one was exploiting opportunities and the second was promoting the brand. ${ }^{12}$

The 1890 Select Committee on British and Foreign Spirits asked an analytical chemist, Dr Bell, to test the whisky sold in the Houses of Parliament which was, of course, Buchanan's blend (see Appendix for more detail on Dr Bell's whisky test). This whisky test was seemingly conducted in order to aid the committee's deliberations over the correct labelling of spirits and to establish if products should state the country of origin. The Committee was particularly keen to gather scientific data and opinions on the differences between blended whiskies and malt whiskies, and on the purity and strength of whisky and other spirits. The House of Commons whisky brand fared well from Dr Bell's chemical analysis and Buchanan wasted no time in promoting the Committee's findings through bottle labelling (see Figs. 7.1, 7.2, and 7.3) Buchanan used bottle labelling as the chief way to cultivate an elite status for his brands of whisky and no opportunity was missed to convince people that Buchanan's whisky was the favoured drink of the social elites.

Buchanan secured royal warrants from Queen Victoria in 1898 and further royal warrants followed in 1901 from Edward VII and in 1910 from George V. This led to the marketing of the 'Royal Household' brand of whiskies which filled the gap left when the decision was taken in 1904 to officially change the 'House of Commons' brand to 'Black and White'. Although the supply to the House of Commons still appeared on labelling after this date, it was less blatant until it was finally removed in 1915. In most historical accounts the reason given for this change is 


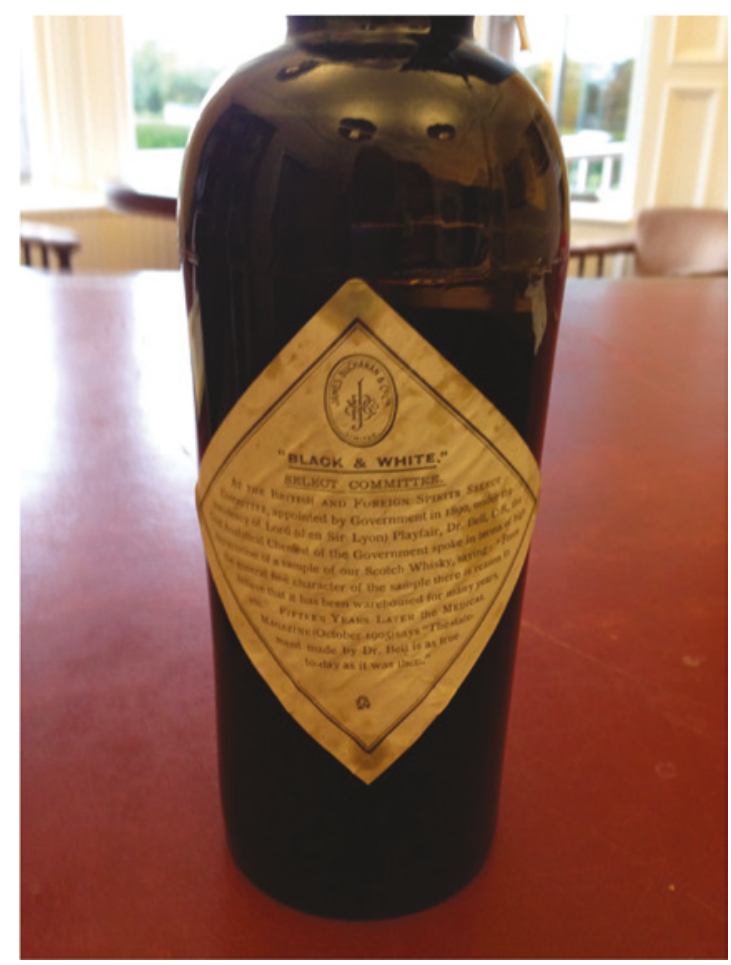

Fig. 7.1 Diageo Archive (DA): Buchanan's whisky bottle c. 1905, Courtesy of Diageo PLC ${ }^{13}$

that due to the design of the bottle customers began asking for 'that black and white whisky' (see Fig. 7.1). This suggests that the company were responsive to consumer feedback and demands and were therefore willing to cast aside social emulation in favour of more straightforward marketing tactics. This may have been true but it is not the only reason why the House of Commons branding was eventually withdrawn. The records of the House of Commons Kitchen Committee in conjunction with Buchanan's personal correspondence reveal the controversial nature of the company's marketing strategy and the determination to pursue it.

When Buchanan secured the contract to supply the Houses of Parliament in 1885 he saw the advertising potential of this deal. The words 'as specially selected for the House of Commons' appeared along 


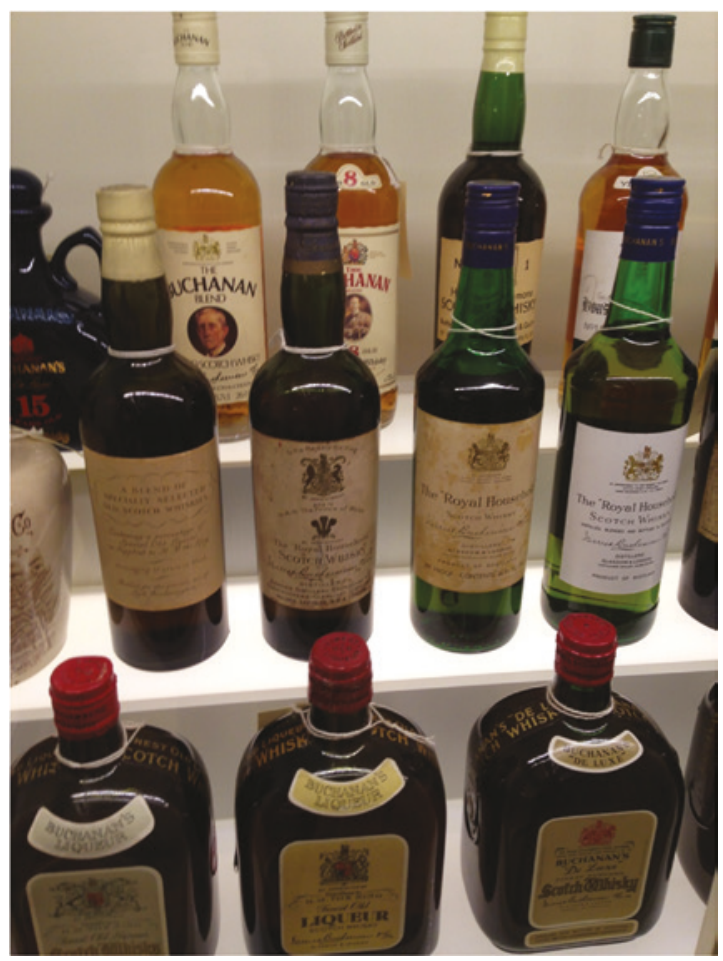

Fig. 7.2 DA: Buchanan's bottles featuring 'The Royal Household' labels c. 1910, Courtesy of Diageo PLC

with pictures of the Houses of Parliament on the labels of Buchanan's blended whiskies. Companies that supplied goods to the royal family also used this style of advertising on their products and therefore it must have seemed logical to promote the contract with the Houses of Parliament. However, the House of Commons Kitchen Committee which was responsible for the purchase and sale of alcoholic drinks within Parliament appeared to take exception to Buchanan's marketing tactics and in 1895 the order to supply whisky went to another firm. In November 1895 Buchanan wrote a letter to W. Tudor Howell MP, an acquaintance who had recently been elected to parliament, complaining that his contract to supply whisky to the House of Commons had not been renewed 


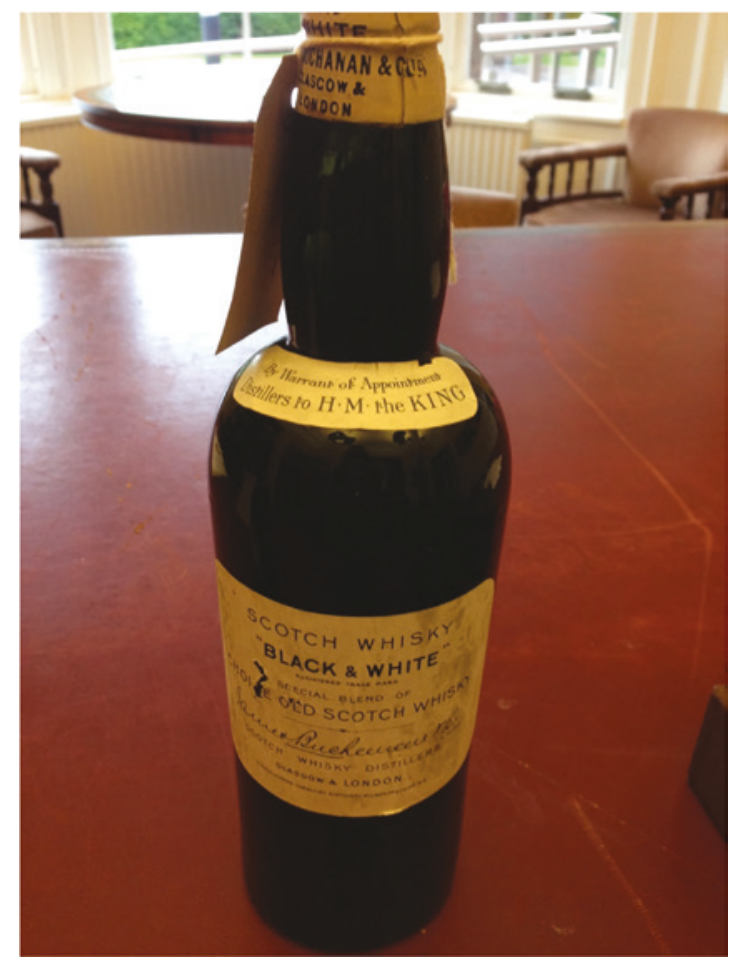

Fig. 7.3 DA: Buchanan's black and white whisky bottle c. 1910 labeled 'by warrant of appointment distillers to H. M. The King', Courtesy of Diageo PLC

I supplied Messrs.' Alexander Gordon \& Co. Refreshment Contractors to the House of Commons with Scotch whisky, from December 1885 until the time when the House took the Refreshment Department under its own control. After this I continued to supply Scotch Whisky to the House and in December 1886, I was officially notified by the Kitchen Committee, that I was appointed supplier of Scotch Whisky to the Kitchen Department. Indeed, up to April 1893, I had practically the entire supply in my hands. Never at any time was there complaint ... At the opening of the House in February 1893, I did not receive the customary order to supply. I called upon Mr Saunders, the Caterer, to ascertain the cause of this, as there had not been one word of complaint and no communication of any kind from the Committee. Mr Saunders informed me that 
the Committee had expressed displeasure at my making use, as an advertisement, of the fact that I supplied the House of Commons with Scotch Whisky. ${ }^{14}$

The letter went on to say that Buchanan believed that he had 'only done what any other firm would do' and used the examples of firms advertising the supply of goods to the royal household. He also pointed out that his replacement (another whisky supplier Messrs.' Denman \& Co.) were now using the House of Commons supply as a form of advertisement on bottles and business cards and he, therefore, felt that he had been particularly targeted

But the great injustice to me is this. My whisky, which has all along been associated with the House of Commons, is understood by the public generally, and asked for as 'The House of Commons Blend'. The Trade now know that I do not supply the House, and this cessation of custom is doing me harm, as it is naturally assumed that my whisky has been dropped for good cause. ${ }^{15}$

Although there was no further correspondence to or from $\mathrm{Mr}$ Howell about this matter, presumably the letter had some effect because by 1901 Buchanan was once again supplying the Houses of Parliament with whisky. Labels on Buchanan Blend whisky from 1896 featured an extract from a letter sent by the manager of the Refreshment Department in the House of Commons, which confirmed that Buchanan had secured the order to supply whisky to the department 'until further notice.' ${ }^{16}$ Other labels stated 'The Buchanan Blend, Special quality fine old Scotch whisky as supplied to The House of Commons' or 'As supplied to The House of Lords.' ${ }^{17}$ So despite losing and then regaining the contract, Buchanan calculated that the benefits of advertising outweighed the risks. The success of Buchanan Blend rested upon its reputation as an elite drink and it was, therefore, vital to ensure continued consumer confidence in the product.

The records of the Kitchen Committee reveal that they remained displeased with the use of the contract as a form of advertising. In the committee meetings of June 1901, there were discussions of sourcing other whisky firms to fill the newly installed whisky vat. ${ }^{18}$ However, in July, it was resolved that the whisky vat should be filled 'on this occasion' with Buchanan's blend and that Mr Buchanan should be informed that filling 
the vat in the House of Commons should not be used as an advertisement. ${ }^{19}$ Once again Buchanan chose to ignore this warning and carried on using the contract for advertising purposes. In 1905, the newly launched Black and White Blend labels included the statement 'Black and White specially selected for the House of Commons. ${ }^{20}$ Interestingly the Kitchen Committee, although clearly unhappy with the unwanted advertising, continued to order Buchanan's whisky. In March 1909, the committee once again discussed changing whisky suppliers but agreed to go with Buchanan. It is not clear from the records whether this was a financial decision or one based upon a preference for the whisky. In March 1912, it was again resolved to order Buchanan's whisky but noted that Mr Buchanan 'should be told to stop using this contract for advertising and trading purposes. ${ }^{21}$ However it took three years for Buchanan to take any notice and in 1915 all reference to the House of Commons was removed from labelling and from then on-until the 1990s in fact, the House of Commons brand was not sold to the general public but only within parliament. The timing of the move may have had something to do with the wartime restrictions on alcohol and it may have seemed inappropriate to draw attention to alcohol consumption within parliament. Yet Buchanan's reluctance to bend to the will of the Kitchen Committee any sooner is understandable: The company had staked its reputation on the supply of products to the highest institutions in the country and used advertising as a means of cultivating and promoting the idea that Scotch was a respectable drink. By 1915, these objectives had been achieved and therefore removing the House of Commons branding but maintaining the supply was a logical concession.

Buchanan \& Co. invested time and money in formulating and implementing many other advertising strategies besides bottle labelling. By the turn of the century, the company was already a visible presence in London due to its delivery horse and carts, which were distinctive because all the horses were of the same breed, and were well trained and groomed. The drivers were smartly dressed and the vans were highly polished and clearly showed the Buchanan company name. By this time the company had developed a range of different whisky brands which varied in terms of price, age and strength. In 1897 Buchanan wrote to an old acquaintance in Kilmarnock, who was a master blender, to ask for advice on developing a cheaper brand of whisky 'I am anxious to get as successful a result as I can, and I am very desirous of getting the order, which will be large; but unfortunately it will be principally entirely a matter of 
price. 22 In the 1890 s when alcohol sales were falling, it was important to promote cheaper products in order to broaden and develop the domestic market. The company began using the trade press for advertising and between 1897 and 1898 adverts appeared in periodicals with a picture of Buchanan Blend along with a quote from The Lancet which stated 'Our analysis shows this to be a remarkably pure spirit and therefore well adapted for medicinally dietetic purposes'. The main advert heading stated 'Ordered by MPs and Doctors'. Adverts also appeared in illustrated weekly newspapers and provincial newspapers. ${ }^{23}$

Between 1904 and 1910 the subject of advertising was a constant theme raised at company board meetings. Buchanan sought to expand the business in England and Scotland and one of the most promising ways to do so was through the use of railway advertising and the sale of whisky in railway refreshment rooms, buffet cars and hotels. In September 1906, it was agreed that advertising show cards should be placed in North Eastern Railway refreshment rooms. It was resolved to increase advertising costs to one pound per show card per annum for not more than 30 show cards. ${ }^{24}$ Over the next few years, the committee also agreed to place posters and show cards in the Midland, Great Northern Railway, London and South Western Railway, G\&R and Bakerloo railway lines. It was proposed that the posters displayed in refreshment rooms and stations featured 'Morning Nip' advertisements, presumably encouraging consumers to drink Buchanan's whisky on the morning commute to work. Between 1908 and 1909 there were discussions of expanding advertising to the Eastern counties and Scotland and it was decided to place posters in the principle railway stations in Scotland and to accept advertising space at Glasgow Central Station for $£ 100$ per year. It was also agreed to place posters at various other Scottish railway stations and to pay 12 guineas to Highland Railway for stocking Buchanan's whisky for sale in buffet cars and in hotels. In addition, the committee agreed to advertise in Liverpool and surrounding stations to the total of 100 posters. $^{25}$

Other advertising strategies were discussed such as theatre and hotel advertising but only certain 'high class' venues such as The Ritz hotel and The Lyric Theatre were deemed suitable. At one board meeting in February 1908, the subject of playing cards cropped up. The company had received letters from customers and others suggesting playing card advertising for the home trade but the suggestion was unanimously dismissed. This seems strange because the company had been reaching out 
to a broader range of consumers through newspaper and railway advertising, which suggests a strategy of selling products to consumers of all social classes but perhaps the association of playing cards with gambling was viewed as undesirable.

After 1910, the company developed the Black and White brand advertising which used the concept of 'black and white' to symbolise the ideals of British imperialism. The adverts initially featured two dogs: one a West Highland terrier and the other a Scottish terrier-one black and one white. The dogs had 'character' and breeding and they were distinctive because of their colours, which were contrasting and oppositional. Yet despite their differences the dogs always stood together, side by side, sometimes fighting a common enemy. For example, an advert from 1909 (Fig. 7.4) showed the two dogs sitting side by side with the caption 'Still Watchers' while another advert from 1910 featured the black and white dogs chained together chasing a rat and a cat. ${ }^{26}$ The advertising also drew upon other 'black and white' themes such as the black and white women advert from 1909 (Fig. 7.5), which showed a 'black' woman walking behind a young 'white' woman in a manner suggesting a colonial mistress and maid relationship. Like the dog adverts, the concept of black and white represented a contrasting but seemingly complimentary relationship - there could not be one without the other; the white needed the black and vice versa; the colours represented a 'good blend' like the Scotch.

\section{BUCHANAN'S SCOTCH WHISKY}

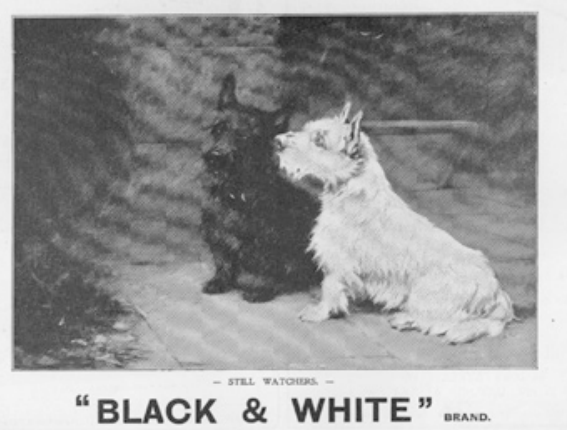

Fig. 7.4 DA: Buchanan's Black and White advert: 1909, Courtesy of Diageo PLC 


\section{BUCHANAN'S WHISKY}

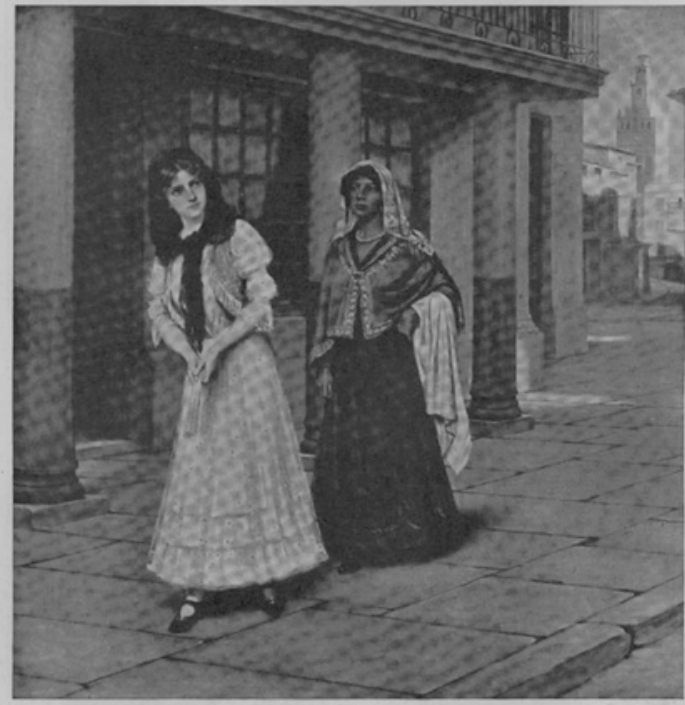

\section{"BLACK \& WHITE"}

Fig. 7.5 DA: Buchanan's Black and White advert: 1909, Courtesy of Diageo PLC

Of course, Buchanan was not the only company to commodify British imperialism. An advert for Four Crown Scotch Whisky that appeared in the trade journal The National Guardian in September 1900 ran with the caption 'A Powerful Peacemaker' and showed a sketch of soldiers and prisoners in an army camp during the Boer War, sharing glasses of whisky. Beneath this scene the advert claimed

While a prisoner of war in Pretoria, The Earl of Rosslyn, in a letter to the London Daily Mail of $11^{\text {th }}$ July 1900 shows, how as soon as the news of Lord Roberts' approach reached the town almost everyone went wild with excitement. He says - "Hollander and Britisher, soldier and Boer peasant, 
prisoner and warder, joined in a mutual expression of esteem and a glass of Robert Brown's Four Crown Scotch Whisky.

By 1900 Scotch was an imperial drink. Companies like Buchanan, Dewar and Walker had built up large export markets using imperial trade links. By this time Buchanan sold products in Australia, New Zealand, India, South Africa, Jamaica, South America, North Africa, Canada and the United States. An advert for Walker's whisky from 1910 showed an image of the famous 'Johnnie Walker striding man' with the caption

Born in 1820 and still going strong - so when someone out in Calcutta or Borneo or Cape Town or Sydney or Valparaiso or any other little jaunt from 'home' laments that he cannot get the good old Scotch they have at 'home', call for Johnnie Walker, let him taste it, and tell him about the vast ageing reserve stock and the ninety years experience that make possible the guarantee. ${ }^{27}$

By 1910, Walker had developed the 'Johnnie Walker striding man' character, which was distinctive and resembled a rather (by that time) antiquated nineteenth-century upper-class dandy. In the adverts, the striding man was 'going strong since 1820' because this was the year when the company first began trading as a licensed grocer in Kilmarnock, Scotland. Like Buchanan, Walker also believed in the power of advertising and of creating a brand image that both promoted and reflected the ideals of British culture and imperialism. In the 1911 'Fashions come and go' campaign, the striding man was inserted into a variety of settings which depicted him as a gentlemanly protector. The adverts showed scenes of Johnnie Walker helping well-to-do ladies step over puddles; shielding them from rain and high winds and 'helping' ladies play a game of croquet. ${ }^{28}$ These adverts drew upon concepts of class and gender in order to sell ideas about whisky to middle-class women who were the group most likely to buy Scotch from licensed grocers. The adverts promoted the idea that Johnnie Walker's whisky embodied the ideals of respectable masculinity - and therefore Scotch was a man's drink but it would certainly 'help' if ladies knew which brand to choose.

The success of companies like Buchanan and Walker lay in the ability to cultivate and expand the domestic and foreign markets for blended Scotch whisky. In Scotland, blended whisky was commonly drunk by the working classes because it was cheap and often bad-either watered 
down or adulterated with other intoxicants. The better quality blended 'Highland' whiskies were often produced in or around the central belt near Glasgow or Edinburgh and were subject to 'Scotch myths' marketing in order to boost sales. James Buchanan went further to completely reinvent blended whisky as a desirable and respectable drink of the British elites. His dogged pursuit of advertising via product labelling ensured that Buchanan whisky became firmly associated with ideas about quality, taste and privilege. The Johnnie Walker striding man is another example of product marketing designed to elevate the status of whisky and to Anglicise it-making it conceptually palatable for the English market. Both companies knew that the use value of whisky as an intoxicant held little currency compared to its cultural value and more specifically, it's potential as a source of cultural capital. Advertising played a key role in this process because it was vital to generate and maintain consumer interest, confidence and loyalty. The economic value of alcoholin terms of expanding the drink trade and generating tax revenue-was largely dependent upon maintaining and developing the cultural value of the substance. If the cultural value evaporated amid a climate of temperance campaigning and legislative controls then there could be no market for alcohol. Therefore, the best way to keep people drinking was to sell them ideas about drinks that veered away from alcohol's primary effect of intoxication and instead promoted contemporary social values. However, as the Gilbey records show, by the turn of the century, maintaining the market for alcohol became more complex as consumers were increasingly drawn towards particular brands of alcoholic drinks that they associated with ideas about quality and taste.

\section{Notes}

1. Townsend B. 2011. Scotch Missed: Scotland's Lost Distilleries: Glasgow: Neil Wilson Publishing Ltd: p. 31.

2. Spiller B. 1984. The Chameleon's Eye: James Buchanan \& Company Limited 1884-1984: London and Glasgow: James Buchanan \& Co. Ltd: p. 8 .

3. Ibid.: p. 9 .

4. Weir R. B. 1982. 'Distilling and Agriculture' in Agricultural History Review: pp. 49-62: www.bahs.org.uk/AGHR/ARTICLES/32nla4.pdf: accessed 4/11/2014.

5. Ibid. 
6. Ibid.: p. 50 .

7. Townsend B. 2011: p. 30.

8. 'James Buchanan's Obituary': The Daily Express: 27 August 1935.

9. Atherton F. W. 1931. History of House Buchanan: No Other Publication Details.

10. Weir R. B. 1974. 'The Distilling Industry in Scotland in the Nineteenth and Early Twentieth Centuries': PhD Dissertation: Edinburgh University: pp. $552-560$.

11. Ibid.

12. Spiller B. 1984: p. 12.

13. The label on the bottle states: At the British and Foreign Spirits Select Committee appointed by the government in 1890, under the presidency of Lord Playfair, Dr Bell, CB, the chief analytical chemist of the government spoke in terms of high appreciation of a sample of our Scotch whisky saying 'From the general fine character of the sample there is reason to believe that it has been warehoused for many years etc.' Fifteen years later the Medical Magazine (October 1905) says the statement made by Dr Bell is as true today as it was then.

14. DA: Acc1033671: Buchanan's Letter Book: 1888-1897: Letter to W. Tudor Howell Esq MP: Dated 9 November 1895.

15. DA: Acc1033671: Buchanan's Letter Book: 1888-1897: Letter to W. Tudor Howell Esq MP: Dated 9 November 1895.

16. DA: Acc 125/3: Buchanan's Label Book: 1896.

17. DA: Acc 125/3: Buchanan's Label Book: 1896.

18. UK Parliamentary Archives (PA): House of Commons Kitchen Committee Records: $\mathrm{HC} / \mathrm{CL} / \mathrm{CO} / \mathrm{EA} / 2 / 2$ : Minute Books: 1901-1905.

19. Ibid.

20. DA: Acc 125/3: Buchanan's Label Book: 1905.

21. PA: House of Commons Kitchen Committee Records: HC/CL/CO/ EA/2/3: 1906-1912.

22. DA: Letter Book: Acc103367/(1/2): 1897-1902: Letter from James Buchanan to David Sneddon: Dated 28 December 1897.

23. Spiller B. 1984: p. 34.

24. DA: Acc 100045/1: Buchanan Minute Books: 1906.

25. DA: Acc 100045/1: Buchanan Minute Books: 1906-1910.

26. DA: 884/43: Buchanan Black and White Adverts: 1910-1911.

27. DA: John Walker 'Striding Man' Advertising: 1908-1911.

28. DA: John Walker 'Striding Man' Advertising: 1908-1911. 
Open Access This chapter is licensed under the terms of the Creative Commons Attribution 4.0 International License (http://creativecommons.org/licenses/ by $/ 4.0 /$ ), which permits use, sharing, adaptation, distribution and reproduction in any medium or format, as long as you give appropriate credit to the original author(s) and the source, provide a link to the Creative Commons license and indicate if changes were made.

The images or other third party material in this chapter are included in the chapter's Creative Commons license, unless indicated otherwise in a credit line to the material. If material is not included in the chapter's Creative Commons license and your intended use is not permitted by statutory regulation or exceeds the permitted use, you will need to obtain permission directly from the copyright holder.

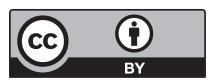

